Nowoczesne Systemy Zarządzania

Zeszyt 13 (2018), nr 4 (październik-grudzień)

ISSN 1896-9380, s. 205-212

Modern Management Systems

Volume 13 (2018), No. 4 (October-December)

ISSN 1896-9380, pp. 205-212
Instytut Organizacji i Zarządzania

Wydział Cybernetyki

Wojskowa Akademia Techniczna

w Warszawie

Institute of Organization and Management

Faculty of Cybernetics

Military University of Technology

\title{
Profile of the contemporary \\ Ukrainian manager - source analysis and characteristics
}

\author{
Profil współczesnego \\ menedżera ukraińskiego - analiza \\ i charakterystyka
}

\author{
Beata Glinkowska \\ Faculty of Management, \\ University of Lodz
}

\begin{abstract}
The inspiration for writing this paper has been an attempt to answer questions about similarities and differences - in relation to the western tendencies - of the personal and competence profile of contemporary Ukrainian managers. Due to volume limitations, and because in the subject literature there is a rather precise definition of the contemporary "western manager", the characteristics of a "western manager" are not cited in this paper. The paper is devoted solely to the analysis and characterization of the characteristics of the contemporary Ukrainian manager. This was possible through personal and direct empirical research. The study consists of two main parts: the background for entrepreneurship in Ukraine and the profile of the Ukrainian manager.
\end{abstract}

Keywords: manager, management, contemporary manager, profile of manager.

Abstrakt. Inspiracją do napisania artykułu była próba odpowiedzi na pytania dotyczące podobieństw i różnic - w odniesieniu do zachodnich tendencji - profilu personalnego i kompetencyjnego współczesnych ukraińskich menedżerów. Ze względu na ograniczenia ilościowe oraz ponieważ w literaturze przedmiotu istnieje dość precyzyjna definicja współczesnego „zachodniego menedżera”, cechy „zachodniego menedżera" nie są cytowane w tym artykule. Artykuł poświęcony jest wyłącznie analizie i charakterystyce cech współczesnego ukraińskiego menedżera. Było to możliwe dzięki osobistym i bezpośrednim badaniom empirycznym. Badanie składa się z dwóch głównych części: podstaw przedsiębiorczości na Ukrainie i profilu ukraińskiego menedżera.

Słowa kluczowe: menedżer, zarządzanie, współczesny menedżer, profil menedżera. 


\section{Introduction}

The main objective of this paper is to build a profile of a contemporary Ukrainian manager based on the analysis of the typical characteristics of the Ukrainian market. The economic situation of every country, as well as the overall level of its development, is largely determined by the nature and quality of governance at national level. It is also directly influenced by the level of professionalism of its management (Glinkowska B., Czebotarov W. , 2016, pp. 141-151). This latter factor has been formalized in the management sciences as a "manager's competence profile". The phenomena and processes reflected in this category derive from the phenomena and processes in the "national business culture" and "corporate culture of the country" categories. The study refers to the concept of a manager's profile and is based on an analysis of the institutional environment and the entrepreneurship level in Ukraine. The research was carried out directly and personally (by the author of this study) in the years 2016-2017, throughout the activities of the Research and Science Cooperation Centre: Poland-Ukraine, whose seat is located at the Faculty of Management of the University of Lodz. The activities of the Centre concerned the development of entrepreneurship as well as problems of internationalization of Polish and Ukrainian organizations. The research conducted in Ukraine was based on gathering of opinions and features of Ukrainian managers of small, medium and large enterprises in the regions of Kiev, Kharkov, Donetsk and Lugansk. Over twenty organizations and twenty-seven managers have been surveyed. A questionnaire and an in-depth interview (according to a certain structure) were used as a research method. The questions posed in the course of the study were, among other things, about the socio-economic and political situation of Ukraine, the conditions of functioning of modern organizations, character traits and desirable competences of Ukrainian managers. In addition, the background for entrepreneurship in Ukraine was analysed.

\section{Background for entrepreneurship in Ukraine}

In the introduction to this paper it is emphasized that the nature and quality of management depend on the level of professionalism of the country's management. The analysis of this aspect is particularly relevant for post-socialist countries, and especially for Ukraine. This is due to the fact that, on one hand there is already some experience in developing the markets of these countries in the recent history (it will soon be forty years since the beginning of market changes in many former socialist countries); and on the other hand the nature and pace of market reforms in some postsocialist countries is far from desirable, but also from objectively possible capabilities of these countries. The latter mainly concerns Ukraine (Epifanova 2009, pp. 211-215). 
According to the canons of the scientific research methodology of all economic phenomena and processes, the starting point for any research should be the analysis of the general conditions for the formation of these phenomena and processes. Therefore the analysis of the conditions for establishing entrepreneurship in Ukraine in the late 80 's and early 90 's is necessary epistemological condition to understand the content of the profile of the Ukrainian manager. The author emphasizes the scientific inaccuracy of the thesis on the alleged appearance of entrepreneurship in Ukraine, as well as in most of the former socialist countries in the mentioned time period (more in: Glinkowska, Czebotarov, 2016, pp. 148-158). From the historical, scientific and epistemological point of view, there is no doubt about the level of enterprise development. For example, entrepreneurship in Ukraine and in Poland, in the last decade of the nineteenth century and early twentieth century, was rated very well not only in the Russian empire but also throughout Europe. This is also confirmed by the multi-faceted activity of Ukrainian bankers - patrons of the Tereshchenko and Brodsky dynasties, the Alchevsky brothers, and in Poland the activity of I. Poznański, S. Bartsinsky, K. V. Scheibler and others. Therefore, there is good reason to talk about the revitalization of entrepreneurship in Ukraine, as well as in other post-socialist European countries, with the transition to market reforms (and, of course, it is necessary to emphasize the features and the characteristics of these processes in each country separately). The most important basic features of the revival of entrepreneurship in Ukraine in the late 1980s and early 1990s were:

- A state sanctioned (even in the former Soviet Union), declarative transition to the market economy without adopting appropriate market transformation programs;

- The official negative attitude towards the entrepreneurial business of the then ruling Communist Party of the Soviet Union, including the administrative and managerial economic apparatus and law enforcement agencies;

- The rejection of the idea of entrepreneurship (in addition to the negative attitude towards it) by the majority of the population (it was definitely less typical of the western regions of Ukraine, which were part of the Soviet Union at the turn of the 30s and 40s.) At the "genetic level" this part of the country has not lost respect for the very idea of entrepreneurship);

- Vague (unclear) establishment character of the first business structures, using often corrupt patterns of economic mechanisms (the overwhelming majority of such structures has a leading role at national, regional and local level);

- Lack of state programs supporting genuine entrepreneurship (primarily small and medium businesses) and superseding of small businesses by large monopolistic and oligarchic business structures.

The unfavourable character of the institutional environment for the revitalization of entrepreneurship in Ukraine makes it difficult to call it intense, however, it is revived since independence, despite the ongoing dominance of communist dogma. 
The idea of entrepreneurship was seriously inhibited over the next three decades by the lack of formulation of the foundations of civil society law and the absence of a national idea (these phenomena were absolutely characteristic until the last three or four years). All this together gave the character of "national business culture", which was not shaped in modern Ukrainian conditions (but it must be objectively pointed out that building a business culture requires time and solid foundations). Such conditions hinder the flexible functioning of Ukrainian entrepreneurs and managers (http://www.old.pafere.org/artykuly,n2547,ciezkie_zycie_przedsiebiorcow_na_ukrainie.html, access: 18. 11. 2017). The great influence of the state on entrepreneurial structures was widely discussed by such authors as A. Veber (Veber 2013, pp. 22-36), as well as L. Klapper, L. Laeven, R. Rajan (Klapper, Laeven, Rajan 2004, pp. 7-59) and V. Lyaszenko (Lyaszenko, 2007, pp. 271-314).

\section{Profile of the contemporary Ukrainian manager}

An analysis of the institutional environment and the level of entrepreneurship in Ukraine was carried out in the years 2016-2017 through studies carried out by the Research and Science Cooperation Centre: Poland-Ukraine. The research concerned the development of entrepreneurship and the problems of internationalization of Ukrainian enterprises, and involved the study of Ukrainian managers from small, medium and large enterprises in the regions of Kiev, Kharkiv, Donetsk and Lugansk, which gave reason to take a closer look at various issues. Referring to the characteristics of the western management model seems sensible when characterizing the "profile" of the contemporary Ukrainian manager. This is reflected in the following statements:

- In the strategic management approach the focus is on outcomes (results);

- In the case of "non-strategic" decisions, a "top to bottom" approach is typical;

- The information exchange system is highly formalized within rigidly established channels;

- The functioning of management systems is highly individualized;

- The division of functional responsibilities in an organization is based on the scheme "from managerial activity to employees";

- Job descriptions are characterized by a series of restrictive laws, regulations and standards;

- The internal planning system is built exclusively on a "top to bottom" model. In the general characteristic above, it can be noted that a high degree of "absolutization" and a kind of "pressure" are both typical for the contemporary Ukrainian manager. In the current Ukrainian reality, the leaning towards the business model of behaviour, the wide application of the business process planning system "from the bottom up", the teamwork nature of work environment, are not reflected in 
the classical characteristics of "Eastern-style management". Many theories cited below could find their reflection in the profile of the Ukrainian manager, if that profile was characterized using the terms and parameters most commonly found in contemporary management theory and if that characteristic was also based on the author's own research.

According to the theory of F. Trampenaars (Trampenaars, Woolliams, 2003, pp. 67-85), the following characteristics are the most apparent for the Ukrainian manager:

- Specialization (as opposed to versatility);

- Collectivism (for the sake of avoiding responsibility);

- Neutrality (with a clear desire to hide their own opinion);

- Diffusion, permeation (a clear boss-subordinate relationship permeates all spheres of the organization's life);

- Ascription (being a member of a collective is largely due to belonging to a particular caste group).

- According to G. Hofstede (Hofstede, 1991, pp. 36-58), the Ukrainian manager is characterized by:

- Collectivism (with no need for self-fulfillment - up to a certain point);

- Highly distanced governing body (honouring the hierarchy in the society seems normal and unwavering);

- Femininity (willingness to resolve conflicts through compromise);

- Avoiding uncertainty (focusing on formalization and regulation within the organization).

According to the theory by R. Lewis (Lewis, 2013, pp. 69-79), using the famous "triangles", the national business culture in Ukraine could be placed in the same area as: Poland, Romania and the Russian Federation. Empirical studies have made it possible to identify and explain the tendency to strengthen the common features of the Ukrainian manager with the Polish model. The empirical work carried out by the Research and Science Cooperation Centre: Poland-Ukraine provides the basis for highlighting the following typical features of the profile of a modern Ukrainian manager:

- He is largely devoid of a sense of leadership (with innate low self esteem), as well as the desire to enthusiastically initiate work and take personal responsibility for the organization and results of business processes;

- For many managers it is a problem to implement business planning in practice (especially given the industry-specific features and changing market conditions), and to develop sound marketing practices and to use intercultural communication technologies;

- At the same time, the Ukrainian manager is a competent and communicative specialist who has mastered the fundamentals of modern management technology and is able to work effectively with the team; 
- For most managers, the typical for the last century 90s approach to earn "much and fast" is no longer valid; The emphasis is on a long and tedious path to career development.

- It is more and more characteristic for the contemporary Ukrainian manager to focus on the continuous development and implementation of innovation, both in production and technology, as well as directly in the organization and in the management of business processes.

\section{Summary}

Analysing the conditions of functioning of Ukrainian organizations it can be concluded that they differ in their content from the Western countries. This translates directly into the profile of the contemporary Ukrainian manager, who is not lacking charisma, however he is overcome by national habits, resulting directly from the post-socialist influence. Building a culture of entrepreneurship takes time and requires a solid foundation, which will have influence for years to come. So far, the dominance of formalization and vertical dependence does not provide a basis for the flexibility of today's Ukrainian companies, especially from the large organizations sector. Small organizations show greater flexibility, but the lack of government support and upbringing overshadowed by high government influence and high formalization does not make it easy on managers who are just starting to apprehend Western trends but do not have the possibility to use them. Ukrainian managers lack leadership qualities that generate enthusiasm from employees who plan and organize their own work. Managers tend to control processes and that deprives their employees of the flexibility of action.

\section{BIBLIOGRAPHY}

[1] EPIFANOva I.M., 2009, Key aspects of small business development in Ukraine / Kluczowe aspekty rozwoju matych przedsiębiorstw na Ukrainie, Materials of the Technical University of Odessa, No. 1 (31).

[2] Glinkowsкa B., Сzевотавоv V.A., Малый и средний бизнес Польши и Украины: проблемьь классификации и исходнье институциональные основы трансформации, [in:] B. Glinkowska (red.), Internationalization of enterprises. Conditions, processes, results of research / Internacjonalizacja przedsiębiorstw. Uwarunkowania, procesy, wyniki badań, Wydawnictwo Uniwersytetu Łódzkiego, Łódź 2016, pp. 148-158.

[3] Glinkowska B., Czeвotarov V.A., Internationalization of Polish and Ukrainian enterprises in modern conditions - general characteristics / Internacjonalizacja polskich i ukraińskich przedsiębiorstw we wspótczesnych warunkach - ogólna charakterystyka, [in:] B. Glinkowska (red.), Internationalization of enterprises. Conditions, processes, results of research, Wydawnictwo Uniwersytetu Łódzkiego, Łódź 2016, pp. 141-151.

[4] Hofstede G.J., Cultures and organizations: software of the mind, London: McGraw-Hill, 1991. 
[5] http://www.old.pafere.org/artykuly,n2547,ciezkie_zycie_przedsiebiorcow_na_ukrainie.html, access 18.11.2017.

[6] Klapper L., Laeven L., Rajan R., 2004, Business Environment and Firm Entry: Evidence from International Data//CEPR Discussion Paper, „Doing business”, No. 4366, https://ideas.repec. org/p/cpr/ceprdp/4366.html, access 18.11.2017.

[7] Lewis R., Fish Can't See Water: How National Culture Can Make or Break Your Corporate Strategy, John Wiley \& Sons, 2013.

[8] Szczepański M.S., Temptations of modernity: Polish development dilemmas / Pokusy nowoczesności: polskie dylematy rozwojowe, Śląsk, Katowice 1992.

[9] Trompenaars F., Woolliams P., Business across cultures, West Sussex: Capstone Publishing, 2003.

[10] VeвеR A., Неолиберальная глобализация и ее противники, 2013, http://www.rassianglobalclub. com/gw_02_07b.htm, access 18.11.2017.

[11] Lyashenко V., Регулирование развития малого предпринимательства в Украине: проблемьь и пути решения, NAN Ukraina, Instytut Ekonomiki Przemysłowej, Donieck 2007. 